\title{
Examining the Effects of Organizational Learning on Workforce Agility through Psychological Empowerment
}

\author{
Derryna Nadhira Putri \& Wustari L. Mangundjaya \\ Universitas Indonesia, Depok, INDONESIA \\ Faculty of Psychology
}

Received: 22 June 2020 • Accepted: 24 September 2020 • Published Online: 6 November 2020

\begin{abstract}
This era currently has become a more competitive and volatile environment. Companies must be invariably innovative, adaptive, and open to any changes. Constant learning and being psychologically enabled at work will lead the employees to be agile. The purpose of this research is to examine the relationship between organizational learning and workforce agility with the moderation of psychological empowerment. This study used a quantitative approach by distributing an online survey to the employees that work in commerce companies with $\mathrm{N}=138$ people. The research data obtained were then analyzed using descriptive statistics, confirmation factor analysis (CFA), and structural equation modeling (SEM). The results showed that organizational learning has a positive and significant relationship with psychological empowerment. Psychological empowerment has a positive and significant relationship with workforce agility, and psychological empowerment fully moderates the relationship between organizational learning and workforce agility. Based on the results of this study, psychological empowerment has an essential role in organizational learning to increase labor agility.
\end{abstract}

Keywords: organizational learning, psychological empowerment, workforce agility.

\section{Introduction}

At present, the implementation of information and communication technology is overgrowing, which has led to industry 4.0 (Vasin et al., 2018). The focuses of industry 4.0 are on the establishment of intelligent products and production processes that transforming the industry and changing various aspects of human life (Brettel et al., 2014). The fourth industrial revolution has changed work environments from assignments-based attributes to the human-focused qualities in various industries, such as government-industry, entrepreneurs, private sectors, and education sectors (Shahroom \& Hussin, 2018). As a result, employees must respond to this dynamic and competitive environment by being agile (Hormozi, 2001). Agility is a fast and appropriate response to changes and threats facing by both organizations and workers (Chonko \& Jones, 2005; Rajan, Solairajan \& Jose, 2012).

As the business grows in competitive markets, the agile organization has been discussed as the most predominant to deal with the uncertain and unpredictable environment (Sherehiy \& Karwowski, 2014). In this regard, workforce agility has been critical and essential to creating an agile organization (Breu et al., 2002; Sherehiy \& Karwowski, 2014). Workforce agility is a proactive, adaptive, and generative behavior of the workforce (Dyer \& Shafer, 2003). Proactive

(C) Authors. Terms and conditions of Creative Commons Attribution 4.0 International (CC BY 4.0) apply. Correspondence: Wustari L. Mangundjaya, Universitas Indonesia, Faculty of Psychology, Depok, INDONESIA. E-mail: wustari@ui.ac.id. 
refers to seeking for opportunities actively to contribute to organizational success and lead in pursuing promising opportunities. There are two aspects of proactive behavior, namely, initiate and improvise. The behavior of adaptive means performing in different capacities across levels and moving from one role to another quickly and simultaneously. On the other hand, Hopp and Oyen (2004) in their study stated that workforce agility has an impact on four aspects of the organization, namely costs, time, quality, and diversity.

- Organizational learning has not a positive and significant effect on workforce agility.

- Psychological empowerment has a positive and significant effect on workforce agility.

- Organizational learning should be integrated with psychological empowerment to improve workforce agility.

There are three dimensions of workforce agility: proactivity, adaptability, and resilience (Sherehiy, 2014). Proactive is the situation when a person initiates the activities that have positive effects on the changing environment, such as anticipate problems related to changes, initiate activities that lead to solutions to problems related to changes and improvements in work, and make a solution of the problems related to changes (Griffin \& Hesketh, 2003). Adaptive refers to change and modification of oneself or one's behavior to better fit a new environment (Griffin \& Hesketh, 2003). For instance, when someone is dealing with people with different backgrounds and experiences, or when learning new skills and tasks. Resilience is one's ability to respond efficiently even under stressful conditions, environmental changes, or experienced failure. These include a positive attitude to the changes, tolerance of uncertain and unexpected, and stressful situations (Sherehiy, 2014).

Studies of workforce agility from Sohrabi, Asari and Hozoori (2014) and Muduli (2016) were associated with organizational practices, such as employee involvement, organizational structure, organizational intelligence, reward system. One of the essential variables related to workforce agility is organizational learning, which is to create employees to become agile by implementing development or training programs (Alavi et al., 2014; Muduli, 2016). Organizations with a learning environment can encourage employees to be more open to new things and more proactive (Gong, Huang \& Farh, 2009). A learning environment can encourage employees to be more open and innovative in seeking new ideas. Their knowledge and learning skills enhance the ability to adapt and respond to changes (Alavi et al., 2014).

\section{H1: Organizational learning is positively and significantly related to workforce agility.}

Organizational learning is essential for employees to be more flexible and adaptable. Learning itself is how people change in a situation that tends to persist (Spector \& Davidsen, 2006). An organization with a flexible and responsive structure can respond to the new challenges and changes much faster than its competitors (Wujiabudula \& Zehir, 2016). Organizational learning is a method to create new knowledge and gain insight from people's experiences at work (Naranjo-Valencia, Sanz-Valle, \& Jiménez- Jiménez, 2010).

There are four dimensions of organizational learning, namely: commitment to learning, open-mindedness, shared vision, and knowledge sharing that managers should develop (Alavi et al., 2014). Commitment to learning is the extent to which organization values and promotes learning and fosters a learning environment (Wujiabudula \& Zehir, 2016). Committed organizations need to have learned as a significant investment. Open-mindedness is the willingness in organizational to critically evaluate the organizations' operational, such as information across departments and to embrace new innovative ideas to employees (Calantone, Cavusgil \& Zhao, 2002). The shared vision indicates the typical direction for employees in an organization for learning, created by mutual interaction between individuals (Wujiabudula \& 
Zehir, 2016). It affects the learning direction and leads to an increase in the quality of learning (Calantone et al., 2002). Knowledge sharing is how knowledge disseminates and spreads among different departments in an organization, consisting of a collaborative alliance, sharing knowledge, and learning from one another (Wujiabudula \& Zehir, 2016). The information is disseminated and spread by the owner, and its employees absorb it.

The research from Sheikhzadeh, Salarzehi and Yavari (2016) showed a significant and positive relationship between organizational learning and psychological empowerment. Thus, an organization must invest in organizational learning to increase employee empowerment level. Meanwhile, findings of Muduli (2016) showed that learning and training conducted by the organization will provide openness, confrontation, trust authenticity, pro-action, autonomy, collaboration, and experimentation which can foster the workforce to be more agile.

\section{H2: Organizational learning is positively and significantly related to psychological empowerment.}

Psychological empowerment is a set of psychological states needed by someone related to his job to feel a sense of control. The empowerment itself refers to individual beliefs about their role in the organization (Spreitzer, 2007). Four dimensions reflect psychological empowerment: meaningfulness, competence, self-determination, and impact (Spreitzer, 2007). Meaningfulness is the value of a work or task that is related to people's standards; for example, an employee with high meaningfulness has commitment and involvement (Thomas \& Velthouse, 1990). Competence or self-efficacy refers to an individual's belief that he can take the necessary actions at work, for instance, the persistence when facing obstacles (Muchinsky, 2007). Self-determination refers to the behavior that reflects self-expression rather than behavior imposed by the environment (Muduli, 2016). The impact is the extent to which an employee's behavior can have a positive effect on his work environment, such as influencing strategic plan (Thomas \& Velthouse, 1990). Training and development for employees in an organization can improve the workforce's competency, leading to feeling competent (Muduli, 2016).

Psychological empowerment also showed had a positive and significant impact on affective commitment to change (Mangundjaya, 2019), which means that with psychological empowerment, people may commit to change and adapt to the organizational change in the organization. Moreover, Psychological empowerment provides necessary conditions for organizations' improvement of the organizational agility to be more competitive (Shah et al., 2017). The organization should plan a psychological empowerment program to make employees feel empowered and capable. Hence, employees can better respond to customers' needs and adapt to a complex and changing environment. The dimensions of psychological empowerment are keys to promoting workforce agility (Muduli, 2016). Meaningful can motivates the workforce to have a high commitment and more involvement. High competency level of the workforce can increase their readiness to be agile by proactively innovate their skill (Muduli, 2016). Strong selfdetermination prepares the workforce to respond to unexpected requests of customers and interpret external change to act following the organizations' strategy (Chonko \& Jones, 2005). Impact, an employee that feels that they can influence others or the work environment, will be more collaborative across projects, leading to increased agility (Chonko \& Jones, 2005).

\section{H3: Psychological empowerment is positively and significantly related to workforce agility.}

The findings of Muduli (2016) showed that organizational practices, including organizational learning integrated with psychological empowerment, were strongly related to workforce agility. Thus, psychological empowerment is a significant mediator between organizational learning and workforce agility. According to Muduli (2016), organizational learning correlated with psychological empowerment, which is meaningfulness, competence, selfdetermination, and impact to promote workforce agility. An organization needs to adopt suitable 
organizational learning, such as skill development, for enhancing psychological empowerment that can foster workforce agility.

\section{H4: Psychological empowerment mediates between organizational learning and workforce agility.}

The environmental changes led many companies in Indonesia to be encouraged to innovate, such as the commerce industry, including e-commerce. According to Shahjee (2015), ecommerce can be interpreted as the process of buying and selling, exchanging products, services, and information through the internet network. Besides many benefits for customers and providers in this industry, there are several challenges faced, such as high competition, poor logistics, supply chain, and a variety of payments. Many companies are increasingly competing to employ experts qualified in information technology and business management and have a comprehensive understanding of both technical and business capabilities (Yazdanifard \& Zargar, 2012). Hence, learning in an organization is essential to increase employees' skills to make employees flexible and agile in this industry.

This research tries to examine the role of psychological empowerment as a mediating role in the relationship between organizational learning and workforce agility in commerce companies, as Figure 1 below.

\section{Method}

\subsection{Participants}

The data gathered from top managers, mid-level managers, and staff to get a complete picture of these variables. The quantitative method of this study is using a convenience sampling technique, which is a type of nonprobability sampling where participants of the population meet specific criteria, such as easy accessibility or the willingness to participate (Dornyei, 2007).

\subsection{Instruments}

The survey instrument of organizational learning was adapted from Alavi et al. (2014) using a self-report questionnaire. Organizational learning has 17 items measured by four dimensions: commitment to learning, open-mindedness, shared vision, and knowledge sharing. Cronbach's alpha of organizational learning was 0.915. Second, the workforce agility scale adapted from Sherehiy et al. (2008), measuring proactivity, adaptability, and resilience. Each dimension of the workforce agility scale had five items. Cronbach's alpha of workforce agility was 0.813 . Furthermore, the Psychological empowerment scale has 12 items and measured by an employee's psychological state related to his job to feel a sense of control, including meaning, competence, impact, and self-determination. This variable was developed by Spreitzer (2007), then modified and translated by Mangundjaya (2014). The Cronbach's alpha of this scale was 0.897. All the instruments are ranged from 1 (strongly disagree) to 6 (strongly agree). This study employs a Structural Equation Modelling (SEM) to investigate the relationship among variables by using SPSS v. 22.0 and AMOS to analyze data.

\section{Results}

The number of samples of this study was 138 employees in commerce companies in Indonesia. From this number, descriptive analysis through demographic characteristics of the respondents in Table 1 shows that the majority were women as many as 96 (70\%). In terms of age, most respondents have the range of age $20-30$ years amount to 115 people (83\%), followed by 
respondents aged 31-40 as many as 23 people (17\%). Most respondents have bachelor degrees $(\mathrm{N}=112$ or $81 \%)$, and a master's degree $(\mathrm{N}=19,14 \%)$. In terms of job tenure, 62 respondents $(45 \%)$ have been working in their companies for less than two years. Followed by 60 respondents (43\%) who had job tenure between 2-5 years.

Table 1. Demographic data of respondents

\begin{tabular}{cccc}
\hline Characteristics & Classification & Frequency & $\%$ \\
\hline Gender & Male & 42 & $30 \%$ \\
& Female & 96 & $70 \%$ \\
Age & 20 - 30 years & 115 & $83 \%$ \\
& $31-$ 40 years & 23 & $17 \%$ \\
Education & Senior High School & 4 & $3 \%$ \\
& Diploma & 3 & $2 \%$ \\
& Bachelor & 112 & $81 \%$ \\
Tenure & Master & 19 & $14 \%$ \\
& $<2$ years & 62 & $45 \%$ \\
& $2-5$ years & 60 & $43 \%$ \\
& $>5$ years & 16 & $12 \%$ \\
\hline
\end{tabular}

Table 2. Demographic different test among variables

\begin{tabular}{lrccccccc}
\hline & \multicolumn{2}{c}{ Gender } & \multicolumn{2}{c}{ Age } & \multicolumn{2}{c}{ Education } & \multicolumn{2}{c}{ Tenure } \\
\cline { 2 - 9 } & $\mathrm{t}$ & Sig. & $\mathrm{t}$ & Sig. & F & Sig. & F & Sig. \\
\hline Workforce agility & 2.14 & 0.03 & 1.09 & 0.27 & 0.36 & 0.77 & 0.10 & 0.12 \\
Organizational learning & 1.92 & 0.05 & 0.94 & 0.34 & 0.06 & 0.03 & 0.62 & 0.53 \\
Psychological & 1.35 & 0.17 & 2.61 & 0.01 & 0.52 & 0.66 & 0.91 & 0.40 \\
empowerment & & & & & & & & \\
\hline
\end{tabular}

Table 2 presents the independent t-test on the comparison of male and female of each variable. There were significant differences $(\alpha=0.03)$ in workforce agility between males and females. Meanwhile, it found no significant differences $(\alpha=0.05)$ in organizational learning and psychological empowerment $(\alpha=0.17)$ between males and females. As shown above, there were no significant differences in workforce agility $(\alpha=0.27)$ and organizational learning $(\alpha=0.34)$ of employees aged 20-30 years and 31-40 years. Meanwhile, there were significant differences in psychological empowerment ( $\alpha=0.01)$ between employees aged 20-30 and 31-40 years.

Table 2 also presents the results of one-way ANOVA, which revealed no significant differences in workforce agility $(\alpha=0.77)$ and psychological empowerment $(\alpha=0.66)$ among all levels of education. As shown, there were significant differences in organizational learning $(\alpha=0.030)$ among all levels of education. From the results of one-way ANOVA, it revealed that there were no significant differences in workforce agility $(\alpha=0.12)$, organizational learning $(\alpha=0.53)$, and psychological empowerment $(\alpha=0.40)$. This result implies that although there is some relatively clear mean score difference between participants from different years of services, these differences are statistically not significant.

Further, confirmatory factor analysis (CFA) was conducted to test how well the measured variables represent the number of constructs. The good model fit would be justified with several goodness-of-fit indices such as; Chi-square $\mathrm{X} 2, \mathrm{X} 2$ / $\mathrm{df}<3$; Root mean square error appropriation, RMSEA $\leq 0.10$; (Byrne, 2009); comparative fit index CFI >0.90; Tucker-Lewis index TLI>0.90 (Schumacker \& Lomax, 2004). The results of CFA of organizational learning scale showed that the model was fit (X2 / df=1.386, RMSEA=0.053, CFI=0.966, TLI=0.950). The model workforce agility scale was also acceptable fit (X2 / df=1.533, RMSEA=0.062, CFI=0.935, $\mathrm{TLI}=0.888$ ). The third model, psychological empowerment scale was fit (X2 / $\mathrm{df}=1.198$, RMSEA=0.038, CFI=0.989, TLI=0.986). 
Figure 1. Research model

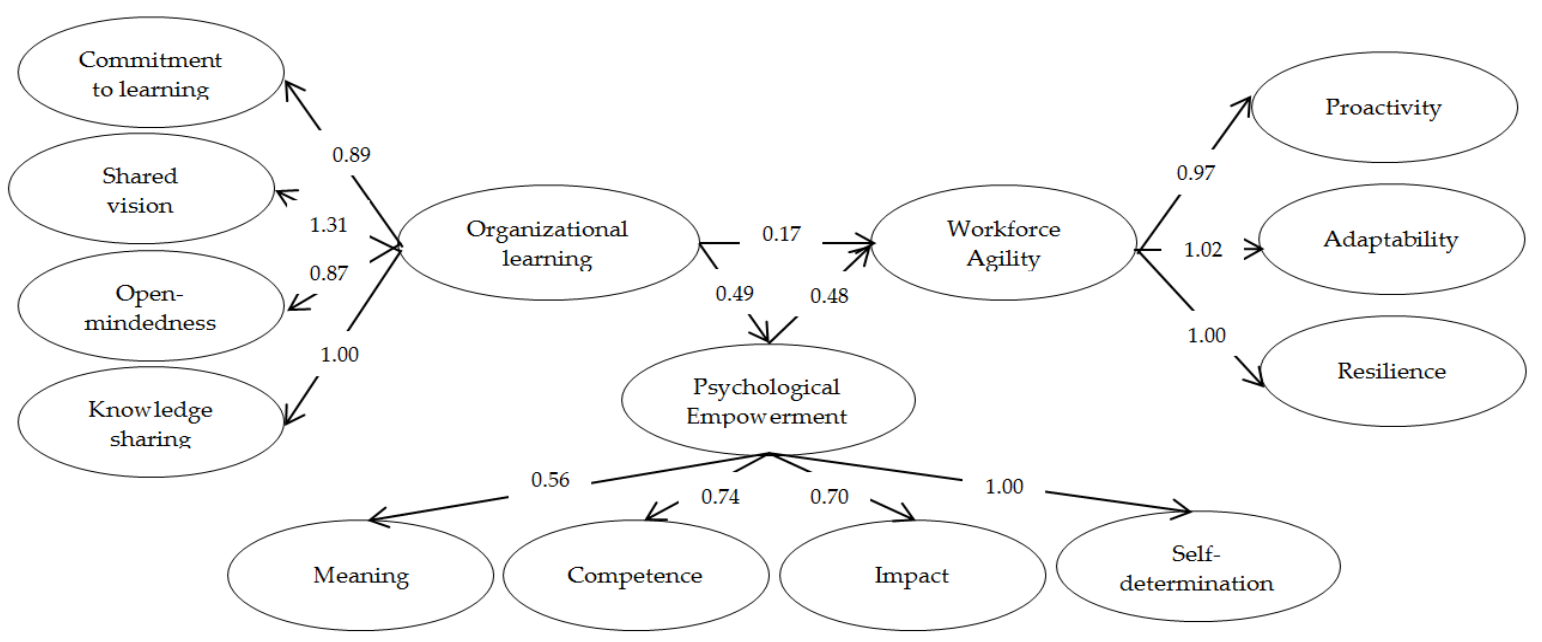

Next, the analysis of measurement model using AMOS shows that the structural model is acceptable fit by following goodness-of-fit indices, such as; $\mathrm{X} 2$ / $\mathrm{df}=1.327, \mathrm{RMR}=0.097$, RMSEA $=0.049, \mathrm{CFI}=0.902$, TLI=0.892. Further, the testing of 4 hypotheses was analyzed based on the result of the analysis of causality relationships between research constructs shown in table 3 .

Table 3. Regression weights, direct effects, indirect effects, and total effects

\begin{tabular}{|c|c|c|c|c|c|}
\hline & Estimate & $\mathrm{P}$ & $\begin{array}{l}\text { Direct } \\
\text { effects }\end{array}$ & $\begin{array}{l}\text { Indirect } \\
\text { effects }\end{array}$ & $\begin{array}{l}\text { Total } \\
\text { effects }\end{array}$ \\
\hline $\begin{array}{l}\text { Organizational Learning } \rightarrow \\
\text { Workforce Agility }\end{array}$ & 0.144 & 0.07 & 0.174 & 0.306 & 0.481 \\
\hline $\begin{array}{l}\text { Organizational Learning } \rightarrow \\
\text { Psychological Empowerment }\end{array}$ & 0.411 & $* *$ & 0.465 & 0.000 & 0.465 \\
\hline $\begin{array}{l}\text { Psychological Empowerment } \rightarrow \\
\text { Workforce Agility }\end{array}$ & 0.617 & $* *$ & 0.481 & 0.000 & 0.481 \\
\hline
\end{tabular}

Table 3 shows the results of the hypothesis. In testing the influence of organizational learning on workforce agility, hypothesis testing indicated that organizational learning has no significant positive effect on workforce agility. Thus, H1 was not supported. Meanwhile, in testing the influence of organizational learning on psychological empowerment, hypothesis testing proved that organizational learning has positive and significant effects on psychological empowerment, or H2 was supported.

The next hypothesis testing is the influence of psychological empowerment on workforce agility. The result showed that psychological empowerment has a positive and significant effect on workforce agility, or $\mathrm{H} 3$ was also supported. It also shows, since the indirect effect on organizational learning to workforce agility is greater than the direct effect, then the mediation occurs. Thus, psychological empowerment fully mediates the relationship between organizational learning and workforce agility, or $\mathrm{H}_{4}$ was supported.

As shown in figure 1, each variable has the contribution of each different factor. Shared vision ( $\beta=1.31$ ) gives the most significant contribution in organizational learning, which means an organization that has a prevailing direction for employees to continuous learning, would have a high impact for employees to be more agile and empowered. This result is also in line with Alavi's (2014) findings, indicating that shared vision has the highest factor loading in relationship with workforce agility. 
The result also showed that self-determination $(\beta=1.00)$ is the highest contributor to psychological empowerment. Thus, the employee who has the autonomy of their work behavior would give a significant impact to mediate organizational learning and workforce agility. According to Chonko and Jones (2006), agile employees must have strong self-determination that can prepare them to respond to customers' unexpected requests.

\section{Discussion}

Organizations should prepare their employee to be adaptive and open-minded to changes in this dynamic environment. Agility is one of the most important things that should be improved to respond. Meanwhile, based on path analysis using SEM, the results obtained from hypothesis 1 indicated that organizational learning does not have a positive and significant effect on workforce agility. The finding is not in line with Alavi's (2014) study, which showed that the atmosphere of learning in an organization encourages employees to be more agile.

However, the results obtained from hypothesis 2 indicated that organizational learning has positive and significant effects on psychological empowerment. Thus, increasing the learning ability, such as training and development of the employee, will lead them to feel more competent. The findings line with the study from Sheikhzadeh, Salarzehi and Yavari (2016), who showed that organizations with an excellent learning atmosphere, open to new knowledge, and commits to learning could increase the empowerment of employee. Thus, learning in an organization is essential to improve employees' self-determination, to feel competence, impact, and meaningful tasks. Besides, the research findings from Rahimian et al. (2014) also showed that there is a positive and healthy relationship between organizational learning and psychological empowerment.

The result of hypothesis 3 shows that there is a significant effect of psychological empowerment on workforce agility. The results are consistent with the research findings from Shah (2017), who showed that psychological empowerment has positive impacts on improving agility. This research is also in line with Mangundjaya (2019) study, which shows that psychological empowerment had a positive impact on affective commitment to change. Thus, people who have psychological empowerment will commit to organizational change and accept and adopt the change, which makes them agile. An employee who has self-efficacy and has a commitment to their work can adapt themselves quickly with unexpected and changing environments. According to Chonko and Jones (2005), agile employees must have strong selfdetermination, which can help them respond to customers' unexpected requests.

This study also showed that organizational learning on workforce agility occurs indirectly and requires mediation by psychological empowerment. According to Muduli (2016), psychological empowerment may contribute to increased flexibility and a more proactive attitude. In other words, organizational practice, such as training and development, is necessary for enhancing psychological empowerment, which can foster workforce agility. It is essential to be considered for managers to create a suitable learning environment in an organization. When an organization practicing learning, their employee feels competent and meaningful at their work. As a result, when employees feel empowered, they will be more capable of responding to their customers' needs, more flexible and adaptable with complex and unpredictable situations.

There are some considerations embedded in this study: First, it recommends that other mediating variables also observed. Many attitude variables can act as mediators of the relationship between organizational learning and workforce agility. Second, to get more comprehensive results, data collection methods can be added qualitatively, such as through interviews and group discussions. 


\section{Conclusion}

This study aims to examine the relationship between organizational learning and workforce agility by exploring psychological empowerment as a mediator in commerce companies in Indonesia. The results showed that organizational learning has a positive and significant effect on psychological empowerment. Furthermore, there is a significant effect of psychological empowerment on workforce agility. However, organizational learning has not a positive and significant effect on workforce agility. These results indicate that organizational learning should be integrated with psychological empowerment to improve workforce agility. This study concludes that companies can encourage their employees' agility, such as to be more open to new ideas, adapt and respond to changes quickly, responsibly to their clients' needs, and be more competitive. They can improve agility by practicing organizational learning that enhances psychological empowerment.

\section{Acknowledgements}

This research did not receive any specific grant from funding agencies in the public commercial, or not-for-profit sectors.

The authors declare no competing interests.

\section{References}

Alavi, S., Wahab, D. A., Muhamad, N., \& Shirani, B. A. (2014). Organic structure and organizational learning as the main antecedents of workforce agility. International Journal of Production Research, 52(21), 6273-6295. https://doi.org/10.1080/00207543.2014.919420

Brettel, M., Friederichsen, N., Keller, M., \& Rosenberg, M. (2014). How virtualization, decentralization, and network building change the manufacturing landscape: An industry 4.0 perspective. International Journal of Mechanical, Industrial Science and Engineering, 8(1), 37-44.

Breu, K., Hemingway, C. J., Strathern, M., \& Bridger, D. (2002). Workforce Agility: The new employee strategy for the knowledge economy. Journal of Information Technology, 17(1), 21-31. https://doi.org/10.1080/02683960110132070

Calantone, R. J., Cavusgil, S., \& Zhao, Y. (2002). Learning orientation, firm innovation capability, and firm performance. Industrial Marketing Management, 31(6), 515-524. https://doi.org/10.1016/s0019-8501(01)00203-6

Chonko, L. B., \& Jones, E. (2005). The need for speed: Agility selling. Journal of Personal Selling and Sales Management 25(4), 373-384.

Dornyei, Z. (2007). Research methods in applied linguistics. New York: Oxford University Press.

Dyer, L., \& Shafer, R. A. (2003). Dynamic organizations: Achieving marketplace and organizational agility with people. Ithaca, NY: Center for Advanced Human Resource Studies, Cornell University.

Gong, Y., Huang, J.-C., \& Farh, J.-L. (2009). Employee learning orientation, transformational leadership, and employee creativity: The mediating role of employee creative self-efficacy. Academy of Management Journal, 52(4), 765-778. https://doi.org/10.5465/amj.2009.43670890

Griffin, B., \& Hesketh, B. (2003). Adaptable behaviours for successful work and career adjustment. Australian Journal of Psychology, 55(2), 65-73. https://doi.org/10.1080/00049530412331312914 
Hormozi, A. M. (2001). Agile manufacturing: the next logical step. Benchmarking: An International Journal, 8(2), 132-143. https://doi.org/10.1108/14635770110389843

Mangundjaya, W. L. (2014). Psychological empowerment and organizational task environment in commitment to change. International Journal of Business and Management, 2(2), 119-126.

Mangundjaya, W. L (2019). Leadership, empowerment, and trust on affective commitment to change in state-owned organisations, Int. J. Public Sector Performance Management, 5(1), 46-62.

Muchinsky, P. M. (2007). Psychology applied to work. Thomson Wadsworth.

Muduli, A. (2016). Exploring the facilitators and mediators of workforce agility: an empirical study. Management Research Review, 39(12), 1567-1586. https://doi.org/10.1108/mrr-10-2015$\underline{0236}$

Naranjo-Valencia, J. C., Jiménez-Jiménez, D., \& Sanz-Valle, R. (2011). Innovation or imitation? The role of organizational culture. Management Decision, 49(1), 55-72.

https://doi.org/10.1108/00251741111094437

Rahimian H., Zamaneh, M. P., Ahmadpour M., \& Piri, M. (2014). A study of the relationship between empowerment and organizational learning among employees of Gas Transmission Company. J. Life Sci. Biomed., 4(6), 550-556.

Rajan, P. V., Solairajan, A. S., \& Jose, C. G. (2012). Agile product development in submersible pump through CAD modeling (CFD). International Journal of Emerging Technology and Advanced Engineering, 2(11), 397-400.

Schumacker, R. E., \& Lomax, R. G. (2004). A beginner's guide to structural equation modeling. Mahwah, NJ: Lawrence Erlbaum Associates.

Shah, Z. D., Majidian Fard, M. B., Lataifian, A., Farahani, R., \& Sahebi, M. (2017). Examining the relationship between empowerment and organizational agility and organizational entrepreneurship in Education Ministry Employees of Lorestan Province. Palma Journal, 16(3), 134-140.

Shahjee, R. (2016). The impact of electronic commerce on business organization. Scholarly Research Journal for Interdisciplinary Studies, 4(27), 3130-3140.

Shahroom, A. A., \& Hussin, N. (2018). Industrial revolution 4.0 and education. International Journal of Academic Research in Business and Social Sciences, 8(9), 314-319. https://doi.org/10.6007/ijarbss/v8-i9/4593

Sheikhzadeh, M., Salarzehi, H., \& Yavari, R. (2016). Investigating the relationship between psychological empowerment of nurses and organizational learning in Iran: A study on Tabriz Imam Reza Hospital. Mediterranean Journal of Social Sciences, $7(5), \quad 371-376$. https://doi.org/10.5901/mjss.2016.v7n5p371

Sherehiy, B. (2008). Relationships between agility strategy, work organization and workforce agility. Kentucky: University of Louisville.

Sherehiy, B., \& Karwowski, W. (2014). The relationship between work organization and workforce agility in small manufacturing enterprises. International Journal of Industrial Ergonomics, 44(3), 466473. https://doi.org/10.1016/j.ergon.2014.01.002

Sohrabi, R., Asari, M., \& Hozoori, M. J. (2014). Relationship between workforce agility and organizational intelligence (Case study: The companies of Iran High Council of Informatics). Asian Social Science, Canadian Center of Science and Education, 10(4), 279-287. https://doi.org/10.5539/ass.v10n4p279

Spector, J. M., \& Davidsen, P. I. (2006). How can organizational learning be modeled and measured? Evaluation and Program Planning, 29(1), 63-69. https://doi.org/10.1016/j.evalprogplan.2005.08.001 
D. Nadhira Putri \& W. L. Mangundjaya - Role of Psychological Empowerment

Spreitzer, G. (2007). Taking stock: A review of more than twenty years of research on empowerment at work. The SAGE Handbook of Organizational Behavior, 1, 54-72. https://doi.org/10.4135/9781849200448.n4

Thomas, K. W., \& Velthouse, B. A. (1990). Cognitive elements of empowerment: An "interpretive" model of intrinsic task motivation. The Academy of Management Review, 15(4), 666. https://doi.org/10.2307/258687

Vasin, S., Gamidullaeva, L., Shkarupeta, E., Palatkin, I., \& Vasina, T. (2018). Emerging trends and opportunities for industry 4.0 development in Russia. European Research Studies Journal, 21(3), 63-76. https://doi.org/10.35808/ersj/1044

Wujiabudula, A., \& Zehir, C. (2016). The effects of organizational learning on firm performance through product innovation. Journal of Global Strategic Management, 10(1), 79-88.

Yazdanifard, R., \& Zargar, A. (2012). Today need of e-commerce management to e-skill trainings. International Journal of e-Education, e-Business, e-Management and e-Learning, 2(1), 5258. 